\title{
OFFICERS AND COMMITTEE
}

\section{New York International Chess} Masters' Tournament

\section{Hotel Alamac, New York}

\section{March 16---April 18, 1924}

\section{PRESIDENT:}

Herbert R. Limburg of New York.

\section{VICE PRESIDENTS:}

Arthur S. Meyer of New York.

\section{TREASURER:}

Dr. Arthur A. Bryant of New York.

\section{SECRETARY :}

Norberi L. Lederer of New York.

\section{BOARD OF TOURNAMENT DIRECTORS:}

Hermann Helms of New York, chairman. Leonard B. Meyer of New York.

Norbert L. Lederer of New York.

\section{COMMITTEE MEMBERS:}

Harold M. Phillips of New York. Dr. Louis Cohn of New York. Felix E. Kahn of New Y rk. Julius Finn of New York. Leonard B. Meyer of New York. Robert Raubitschek of New York. Maurice Wertheim of New York. Horace R. Bigelow of New York.
Albert H. Loeb of Chicago.

Walter Penn Shipley of Philadelphia. John F. Barry of Boston. William M. Vance of Princeton. Edward L. Torsch of Baltimore. Carl van der Voort of Pittsburgh. Stirling Kerr of Washington.

Francis $\mathrm{H}$. French of Davenport. 